\title{
Research on Innovation and Entrepreneurship Education of Tourism Management Specialty in Colleges and Universities Based on School Enterprise Cooperation
}

\begin{abstract}
Xixi Zeng
Jiangxi V\&T College of Communications, Jiangxi, Nanchang,330038

739960103@qq.com

ABSTRACT

With the development of China's education to the stage of comprehensive quality education for student groups, colleges and universities pay more and more attention to the comprehensive quality of student groups. Among them, colleges and universities also strengthen the innovation and entrepreneurship education of tourism management specialty on the basis of paying attention to cooperation with enterprises. This paper mainly studies the development and thinking of innovation and entrepreneurship education of Tourism Management Specialty in Colleges and universities on the basis of school enterprise cooperation. According to the research and development, at present, the innovation and entrepreneurship education in Colleges and universities often needs the cooperation between schools and enterprises, but there are still many problems in the innovation and Entrepreneurship of Tourism Management Major in Colleges and universities on this basis. This paper also puts forward corresponding solutions, hoping to provide reference value for relevant research.
\end{abstract}

Keywords: innovation and entrepreneurship, School enterprise cooperation, tourism management

\section{基于校企合作的高校旅游管理专业创新创业教育探究}

\author{
曾希熙
}

\section{江西工业贸易职业技术学院学院 江西 南昌 330038 \\ 739960103@qq.com}

摘要:

随着我国的教育事业发展到学生群体全面素质教育阶段, 高校对于学生群体的综合素质越来越重视, 在这其 中高校也在重视与企业合作的基础上加强了旅游管理专业的创新创业教育。本文主要在于研究在校企合作的 基础上对于高校旅游管理专业创新创业教育的发展与思考。根据研究发展就目前来说高校的创新创业教育往 往是需要校企合作的, 但是在这个基础上的高校旅游管理专业的创新创业仍旧存在很多问题, 本文也提出了 相应的解决措施, 希望可以给相关研究提供参考价值。

关键词: 创新创业; 校企合作;旅游管理

\section{1. 校企合作在创新创业教育中的重要性}

对于高校专业旅游管理来说，必须对其进行创 新创业教育发展, 才能够有效的发挥该专业的学生 价值, 并且能够跟随的时代的潮流进步。发展创新
性的教育一直是国家实现创新驱动力发展的重要举 措, 而且对于高校的旅游管理专业来说也可以为社 会培育相应的创新型旅游管理人才, 从而促进国内 旅游业的发展。在育人方面, 高校与企业的积极合 作能够有效的培养旅游管理专业高质量人才，在此 基础上进行的人才教育往往对于国家而言更具有现 
实意义。因此要想推动国内旅游业的发展, 就必须 在校企合作的基础上培育具有创新精神和创业意识 的高质量旅游管理人才。

对于现代社会而言, 市场的发展往往会分析出 社会与人们的总体需求, 当前我国的旅游业开始进 入发展的黄金时期, 因此全国众多的旅游业就需要 大量的旅游管理专业创新型人才, 在此基础上还需 要旅游管理人才具有很强的主观能动性、对于旅游 管理的积极性以及对于旅游行业的远见创新性, 只 有做到这三点才能够有效的推动当前的旅游业发 展。对于创新型和创业型旅游管理人才来说, 其本 身的本质在于能够对本专业和行业有着深刻的了 解, 其中就包括基础知识、基础管理技能、与本行 业有关的法律法规等等, 还需要行动上有自己的主 见与意识, 能够与人进行无障碍沟通以及个人实践 能力。因此对于此类人才的培养往往需要高校与企 业进行合作, 两者合作的好处主要可以体现在两个 方面, 一方面高校可以通过扎实的理论知识对人才 进行基础上的培育, 任何创新创业都离不开优秀的 文化基础。另一方面, 企业可以为高校优秀的旅游 管理人才提供将理论实践的平台, 有效的培育人才 的各个方面, 还有可以为企业提升综合实力。结合 两个方面, 往往可以看出高素质旅游管理人才是需 要企业与高校共同培养的, 人才的培育有利于为学 生群体创造机会, 也有利于高校企业提升实力, 对 于双方而言都是能够从中获利的, 这样培育的旅游 管理人才往往可以拥有扎实的基础与实践能力, 对 于创新能力也有着强大的建设运用。

\section{2. 旅游管理专业创新创业教育存在问题}

\section{1. 观念滞后，创新创业氛围呕待营造}

对于创新人才的发展, 国家始终在重视创新创 业教育的落实与进步, 对于高校教育事业的发展也 在大量培育创新型人才队伍。就目前的高校教育来 看, 主要带来创新型人才培育困难的是教师群体的 观念老旧, 单一, 往往大部分的高校教师群体都没 有让自身的观念跟随时代发展, 目前高校教师群体 主要存在的问题在于十分重视理论知识的教育, 而 忽略了学生的综合性发展, 在一定程度上降低了学 生的自主创新能力。面对这种情况就需要高校采取 相应的措施来进行改善, 就比如成立相应专业的创 新型人才培育计划、制定人才培育方案、对教学方 式与模式进行改革等等。所以对于创新型人才培育 的不重视往往限制了当前教育事业的发展。

\section{2. 人才培养方案与创新创业教育的需求契 合度不高}

对于高校而言, 人才的培育也就有多样性。高 校的相关人才培育计划与方案, 往往没有重视创新 型人才的培育, 这样很难做好创新创业教育的发
展。其中主要在于对人才培育的定位偏差, 就比如 我国著名高校华南农业大学的旅游管理专业培育人 才方案, 方案的核心在于如何培育学生的分析解决 问题能力以及创新创业能力, 方案的核心与实际的 培育过程存在很大的偏差, 偏差的重点在于理论扎 实的基础上难以对学生进行实践教育, 就很难培育 出综合素质强的创新型人才。不仅如此, 制度上以 及实际经费上的制约也难以让学生完成相应的任务 与目标, 打击了学生的创业热情。所以对于创新创 业人才的培育, 仍旧需要重视学生的理论用于实 践。

\section{3. 教学模式过于单一, 缺乏灵活性}

对于旅游管理专业的创新创业教育来说, 课程 教育改革是不可或缺的重要举措。当前课堂的教育 模式主要还是以教师群体为中心对学生进行理论教 育, 这种单一的教育方式往往会难以激发学生的主 观能动性以及学习兴趣, 这从学生发展的角度来 说, 制约了学生的创新性、主动性发展。并且学生 群体的创新型意识将意识扼杀在应试教育的体系 中。所以对于高校教育模式的不重视也是制约学生 发展创新性的重要难题。

\section{4. 师资力量薄弱}

教师作为学生学习与发展的指路人, 往往能够 有效帮助学生走向自我实现的道路, 其中也包括创 新型人才的走向。就目前的高校旅游管理专业来 看, 对于如何培育该专业的创新型创业型人才的教 师群体仍旧没有底蕴, 这样就会导致教师群体难以 发展优秀的旅游管理专业人才, 拖后了旅游管理专 业的发展。并且由于教师人才队伍的力量薄弱, 很 难可以去为学生进行创新型思维的锻炼, 从而导致 学生群体难以将理论运用到实践中来, 再加上部分 教师群体对于创新创业指导的不重视, 走流程和形 式型上课方式的出现, 使得高校很难培育出优秀的 创新型人才。

\section{5. 缺少创新创业实践平台和激励保障机制}

高校对于专业的创新发展也存在着许多专业的 缺失, 比如没有让旅游管理专业学生拥有属于自己 专业的创新创业平台, 导致缺乏实践与锻炼, 难以 成就创新型人才的培育。虽然在目前现存的平台 中, 高校也会安排相应的交流会、创新项目讨论会 以及专业创新创业讲座等等, 这只会在一定程度上 提高学生的自我创新意识, 本质上没有实际的实践 成果去推动学生发展创新实践能力, 并且没有真正 的企业实践人员进行指导, 往往会使得学生对创业 没有安全感。不仅如此, 高校的创新创业教育往往 没有重视对视资金，人力以及物力的投入，还有国 家的政策支持不到位的现象都体现目前的创新创业 教育没有对学生创新创业知识进行落实, 并且没有 
相应的企业进行支持, 难以发展创新型人才推动旅 游管理行业发展。

\section{3. 校企合作背景下开展创新创业教育的对策}

\section{1. 积极营造创新创业気围}

针对高校目前创新型校园氛围的问题, 必须重 视学校整体对于专业创新的意识, 对于旅游管理专 业来说实践是十分重要的, 因此对于旅游管理专业 来说创新创业教育的发展是有利于学生进行实践教 育的落实, 因此学校必须重视对于旅游管理专业人 才培育方案的制定、课堂教学的改革以及实践教学 的落实等等, 把旅游管理专业的创新创业教育与理 论教育有机结合起来, 才能够真正意义的上营造优 秀的创新创业校园氛围, 引导学生们发挥自身的创 新意识从而成为旅游管理专业的高素质创新型人 才。

\section{2. 加强企业与校方的合作，共同制定人才 培育方案}

高校可通过与企业加强合作, 在制定相应创新 型人才培育方案方面, 可以引进企业专业人员参与 方案制定过程中来, 高校必须在制定方案的过程中 听取旅游企业对于市场相应的需求分析, 来对学生 群体进行创新型人才的培养。往往是企业工作人员 可以更好的对当前旅游业发展趋势进行分析, 然后 将市场中所需求的旅游业创新创业人才培养应用到 高校中来。因此校企合作的核心在于对于高校理论 实践的教育改革, 以及成立相应的实践教学平台, 通过更多的实践实例来对学生进行创新创业上的培 养, 对于人才培育方案, 主要可以关注一下两个方 面。一方面高校不能只仅仅关注旅游业的基础知识 教育。需要在旅游业基础知识上开设相应的旅游企 业创业学运营学课程, 并且还需要开设相应的旅游 业商业项目策划等等讲座, 有效的让学生在进行创 新创业时, 把理论基础了解到位。另一方面高校需 要和企业进行深入交流, 把创新实验平台做好给予 学生优秀的实践资源, 不能仅仅只是重视课程学 习, 还必须保证企业能够在对学生进行实践的同时 有一定的指导, 把旅游业的综合实践时间加长, 让 学生能够在旅游业企业中得到有效的实践训练。结 合以上两个方面可以有效的培育旅游管理专业人 才, 创新创业的教育也可以为旅游业企业提供新的 人才资源。

\section{3. 校企合作, 共同培育创新创业型人才}

首先, 高校可以通过与企业进行交流, 邀请企 业高层管理人员来给学生讲述企业发展的基础知 识。对于旅游业的发展, 社会企业中的旅游业高层 管理人士往往对其未来的前景及其现状发展都十分 了解, 将高层人士的课程安排在高校中, 有利于拥
有创新思维的学生进行创新创业活动, 并且能够有 效的拉近旅游管理专业学生的距离, 高层人士的实 际案例分析, 往往可以有效的填补高校教师行业实 践不足的缺陷。学生也可以有效的了解到当前专业 企业发展的趋势和最新消息。高层人士的实践资源 往往可以与课堂理论知识结合起来, 让学生能够更 好的散发自己的创新性思维。

其次, 高校与企业的合作中必须重视学生的实 践教学。对于旅游管理专业的学生来说, 本身的实 践教学分为很多层次, 每一个城市都有着不同的实 现方法与实践方案, 倘若学生想要去进行了解, 就 必须通过校企合作来实现, 通常需要注重以下几 点。一是高校与企业深入合作关系, 让企业可以为 学生的课程理论实际提供岗位机会来进行实践, 其 中主要包括酒店、旅行社、以及旅游景区等旅游企 业岗位。二试高校通过相应的政策与企业达成合 作, 为企业提供相应的人才, 从而建立起大学生实 践实习基地，把真实的实践模拟运用到实践基地的 建设中来, 同时也可以为大学生就业提供相应的岗 位。三是高校可以通过邀请企业的相关技术人员来 为学生的毕业论文以及创新创业项目指数进行指 导, 从而真正意义上让学生的理论知识得到认可和 改进。四是企业可以通过与高校交流，把优秀的大 学生人才作为企业的新生力量, 也可以把高校中的 教师群体引入到企业中进行相应的学习, 从而把理 论知识与实践结合起来, 有利于高校旅游管理专业 教师群体对学生进行教育, 从而培养学生的创新思 维能力。结合以上试点, 能够有效的把学生的实践 能力与创新思维结合起来, 培育出旅游管理专业人 才的创新型人才队伍。

\section{4. 结论:}

总而言之，在我国的旅游业发展过程中，对于 创新创业型人才的需求是十分巨大的。校企合作往 往能够提供非常优质的旅游管理专业人才, 同时也 可以为我国旅游业发展提供有效的动力。高校的教 育事业也能够通过旅游管理人才的出现而有效的进 行发展, 不仅仅能够发现高校旅游管理专业课程的 缺陷, 也可以有效的解决旅游管理专业人才就业的 问题。企业也可以在此当中获得有生力量, 从而加 强企业人才队伍的建设, 共同推进企业综合实力的 进步。所以在校企合作的基础上，能够有效的推动 高校旅游管理，专业创新创业教育的发展。

\section{REFERENCES}

[1] Gao Xiaojie, Cao Shengli. Innovation and Entrepreneurship Education -- cultivating pioneers in the cause of the new era -- a summary of the seminar on innovation and entrepreneurship education of China Society of Higher Education [J]. China higher education research, 2007 (7): 91-93 
[2] Ding junmiao. Leading the reform and development of higher education with innovation and Entrepreneurship Education - three stages of innovation and entrepreneurship education and the new historical mission of colleges and universities [J]. Innovation and entrepreneurship education, 2016,7 (1): 1-6

[2] Ji Jinxiong, Hong Xiaoyan, Li Yunzhu. Research on practical teaching innovation of Tourism Management Specialty under school local cooperation -- Taking Anxi Tea College of Fujian agriculture and Forestry University as an example [J]. Popular science and technology, 2017,19 (9): 86-88

[3] Zhan LAN, Xie Xinli, Zhong Rongfeng, Zhan Jiali. The path of collaborative training of innovative and entrepreneurial talents in hotel management -Based on the "four helix" theoretical model [J]. Journal of Chengdu Normal University, 2020,36 (7): 9-15

[4] Wang Jinwei. Effect evaluation of innovation and entrepreneurship education in Colleges and universities and students' intention of career choice -- Taking Tourism Management Major of Peking s University as an example [J]. Statistics and management, 2020,35 (1): 125-128

[5] Zhan Yizhou, Liu Hao, Zhang Zhen, Zhou Yi, Li Junfang. Research on integrating business administration curriculum system in innovation and Entrepreneurship Education -- aiming at the establishment and development of start-ups [J]. Theoretical research and practice of innovation and entrepreneurship, 2020 (20): 188-189

[6] Wang Heng, Cao Hongzhen. Construction of tourism management talent training mode under the background of innovation and Entrepreneurship Education -- Taking Liaoning Institute of foreign trade and economic cooperation as an example [J]. Journal of Dalian University for nationalities, 2015,17 (6): 606-609

[7] Ouyang Tiancheng, Huang haozhong. Practice and exploration of innovation and entrepreneurship education reform for College Students -- taking energy and power engineering major of Guangxi University as an example [J]. Educational observation (first half of the month), 2017,6 (11): $45-46$

[8] Zheng Zhihui, Wang Hongwei. Research on the integrated development of innovation and entrepreneurship education and professional education in private colleges and Universities -taking foreign language majors in a private college in Heilongjiang Province as an example [J]. Education and teaching forum, 2017,0 (30): 7-8

[9] Yang Fang, Wu Hongzhen. Construction and practice of "four-dimensional integration" service outsourcing innovation and Entrepreneurship Talent Training Approach -- Reflections on entrepreneurship education in Suzhou Industrial Park Service Outsourcing Vocational College [J]. Vocational education communication, 2017,0 (11): 30-33

[10] Deng Yufu, Liu Ling, Zhang Haohua, Zhang Liqing, $\mathrm{Wu}$ Lijuan. Exploration on the deep integration of innovation and entrepreneurship education and Physics Education [J]. JOURNAL OF SHENYANG NORMAL UNIVERSITY (NATURAL SCIENCE EDITION), 2017,35 (1): 121-124

[11] Li Aidong, Zhao Xiaoyi, Gao Xiaojiao, Zhou Xuezeng, Zhou Bingchen, Ge Hongwei, Li Xinxin. Construction of innovation and entrepreneurship education curriculum system for college students from the perspective of modular education [J]. Journal of Hebei Engineering and Technology College, 2016,0 (4): 60-62

[12] Yan Guanghao, Huyan Wenjuan, Lin Ze. Innovation and practice of the teaching system of entrepreneurship awareness and entrepreneurship plan training based on the improvement of innovation and entrepreneurship ability [J]. Asia Pacific Education, 2016,0 (36): 146-147

[13] Liang Liping, Chen Xiaoqin. Reform of applied talent training mode integrating innovation, entrepreneurship and professional education -taking international economy and trade as an example [J]. Journal of Chifeng University (NATURAL SCIENCE EDITION), 2015,31 (20): 223-224

[14] Zhang zongtao, Xin Rongsheng, Li Bing, Zhou Ying, Wang Yu, Dong Lin, Jia Xiaolin. Research and Thinking on promoting the cultivation of College Students' innovation and entrepreneurship ability with the "Challenge Cup" scientific and technological activity as the carrier [J]. Journal of Henan Institute of Education (NATURAL SCIENCE EDITION), 2015,24 (3): 70-73 